\title{
Influence of cyclic loading on performance of steel piles in sandy soil
}

\author{
Mohammed Al-Neami ${ }^{1, *}$, Mariam Wasmi ${ }^{1}$ \\ ${ }^{1}$ Building and Construction Engineering Department, University of Technology, Baghdad, Iraq
}

\begin{abstract}
This paper introduces an experimental study to clarify the response of steel pile models exposed to the cyclic loading. Thirty six models of two types of steel piles are tested (open ended pile and H-pile) with lengths equal to $(30,40$, and 50$) \mathrm{cm}$. Three diameters $(2.5,3.5$, and 4.1$) \mathrm{cm}$ for open ended pipe pile and three flange widths $(2.6,3.6$, and 4.4$) \mathrm{cm}$ for $\mathrm{H}$-pile are investigated. Jacking technique is employed to installed piles models in dry sandy samples with two different relative densities $(60 \%$ for medium sand $80 \%$ for dense sand). It is found that the pile geometry (diameter and length) with sand density have a high impact on the number of cycles. Analysis of results showed that increasing of pile diameter and relative density cause a reduction in the number of cycles when the length of steel pile models are fixed while variety of diameters of open ended pipe pile has a small effect on the number of cycles. It was found that pipe piles with open ended have more resistance to the cyclic loading compared with $\mathrm{H}$ piles under the same geometric conditions (pile diameter, embedded length and sand density) especially in medium sand. Finally, if the testing conditions are the same, number of cycles is decreased with increasing in amplitude loading.
\end{abstract}

\section{Introduction}

Many permanent deformations are developed in soil when exposures to cyclic loading which causes serious problems as well as excessive settlement or liquefaction due to a build-up of excess pore water pressure (di Prisco and Wood 2012)[1]. Pile foundations are the most populist constitute of deep foundation utilized alike for offshore and onshore structures. Piles foundation may subject to the cyclic loading as a result of machine foundation vibration, traffic loads, vibration induced due to pile driving, wave action in offshore structures or the naturally imposed vibrations in soil strata due to earth tremors. The effect of cyclic loading may be transmitted to the soil surrounding piles resulting significant rotation or deformation during the piles life which not taking in consideration in design.

Many researchers have been studied the behavior of deep foundation under cyclic loading, some of them are representing in following.

Puech et.al, (1982) [2] conducted a cyclic tensile load on steel piles embedded in silts and loose sands. These tests were performed on $27.3 \mathrm{~cm}$ diameter and $130 \mathrm{~cm}$ long piles. The outcomes of these tests showed that the displacement of piles under cyclic loading divided into a transitory stage, which refers to an immediate response of the soil to the cyclic stresses and a cyclic creep stage. For reduced load levels (less than $50 \% \mathrm{Q}_{\text {ult }}$ ), the displacement rate decreases, indicating stability and for higher load levels (greater than $50 \% \mathrm{Qult}_{\text {ult }}$, the rate of displacement increases loading to failure, similar to those observed by Chan and Hanna (1980).

Poulos (1984, 1989a and 1989b) [3, 4, and 5] made experimental and analytical studies on the small piles models in sand. The results of these studies showed that the cyclic deterioration of skin friction is controlled by the amplitude of cyclic displacement, relative to a critical displacement. This critical displacement is equal to the static displacement required for full slip.

Craig and Sabagh (1994)[6] concluded from testing the aluminum pipe installed in dry sand by jacking method that the shaft capacity degraded significantly in the smaller-diameter piles when the cyclic displacement exceeded a threshold which was in the order of displacement required to completely mobilize the shaft resistance.

Jardine and Standing $(2000,2012)[7,8]$ demonstrated that axial cyclic loading affects the behavior of full scale piles driven in the sands. Low-level tension axial cycling (with load cyclic amplitude $\mathrm{Q}_{\text {cyclic }}<\sim 20 \%$ the operational static shaft capacity QT) led to minimal cyclic displacements that accumulated at stabilizing rates with almost no impact on pile stiffness and potentially enhancement of the pile's static tension capacity.

$\mathrm{Yu}$ et al. (2006) [9] studied the behavior of jacking $\mathrm{H}$ pile embedded in dense sand under cyclic loading. They showed that the effect of previous loading cycles on pilesoil stiffness and load distribution was insignificant.

$\mathrm{Yu}$ (2008) [10] conducted a cyclic field test on $\mathrm{H}$ pile installed in dense sand. He stated that the base resistance carried about $60 \%$ of the overall capacity and the shaft

\footnotetext{
* Corresponding author: $\mathrm{Al}$ Neami74@yahoo.com
} 
resistance was contributed mainly by the friction between the pile shaft and the completely or highly decomposed granite.

Jardine and Standing (2012) [8] reported cyclic tests on a $45.7 \mathrm{~cm}$ diameter of six pipe piles with open ends driven in medium to dense marine sands. One cyclic test pile had been driven to $(\mathrm{L} / \mathrm{D}=21.9)$ and others five to about (L/D = 41.6). Subsequently, most of the cyclic loading suites delimit the influences of the prior cyclic loading. Figure1 summarized the cyclic parameters investigated in a normalized (non-dimensional) axial cyclic interaction diagram whereas the three zones of response, Stable (St), Metastable (MS) and Unstable (US), were characterized that defined the piles capacity performance.

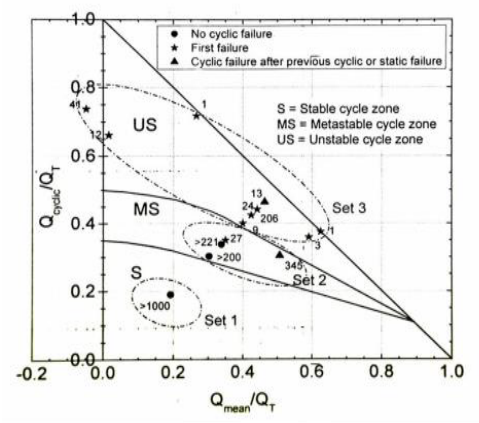

Fig.1. Interaction diagram on axial cyclic response of displacement piles (Jardine \& Standing 2012).

Li et al. (2013) [11] studied the impact of installation methods on the jacked piles performance subjected to the cyclic vertical loads. They showed that the jacking pile is stiffer to cyclic response than bored pile. The stiffness of pile head reduces with increases the number of cycles and a bored pile showed a more settlement than jacked pile.

The main objective of this work is to study the behavior of steel piles (open ended pipe piles and $\mathrm{H}$ piles) installed by the jacking method in dry medium and dense sand under cyclic load and making a clear picture of the effect of amplitude load on the number of cycles.

\section{Methodology}

\subsection{Materials used}

Air-dried sand brought up from east of Baghdad in Iraq was used in this study. The soil is classified as poorly graded sand (SP) according to USCS as shown in Figure 2. Series of laboratory tests were conducted to distinguish sand accordance with ASTM Specification. Two relative densities were used (medium sand and dense sand) and the direct shear test gave that the friction angles are $31.5^{\circ}$ and $38.7^{\circ}$, for medium sand $(\mathrm{DR}=60 \%$ ) dense sand $(\mathrm{DR}=80 \%)$ respectively. The outcomes of experimental testing are summarized in Table1.

Piles models used in this study are divided into groups (Figure 3); the first one is open ended steel solid pipe with diameters $(2.5,3.5$, and 4.1$) \mathrm{cm}$. secondly is $\mathrm{H}$ piles with three flange widths $(2.6,3.6$, and 4.4$) \mathrm{cm}$. Eighteen models are used for each model with three lengths (30, 40 , and 50$) \mathrm{cm}$.

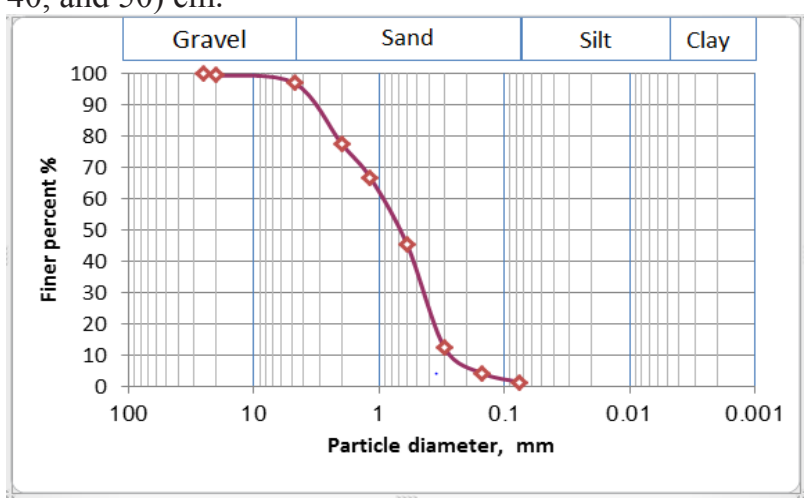

Fig. 2.Grain size distribution of sand used.

Table 1. Physical properties of the tested sand.

\begin{tabular}{|c|c|c|c|}
\hline Property & \multicolumn{2}{|c|}{ Value } & Specification \\
\hline $\begin{array}{l}\text { Effective sizes, } \\
\text { D10, D30, D50, } \\
\text { D60. mm }\end{array}$ & \multicolumn{2}{|c|}{$0.29,0.45,0.7,0.9$} & $\begin{array}{c}\text { ASTM D2487 } \\
-11\end{array}$ \\
\hline $\begin{array}{l}\text { Coefficient of } \\
\text { uniformity, } \mathrm{Cu}\end{array}$ & \multicolumn{2}{|c|}{3.10} & \\
\hline $\begin{array}{l}\text { Coefficient of } \\
\text { curvature, } \mathrm{Cc}\end{array}$ & \multicolumn{2}{|c|}{0.78} & \\
\hline $\begin{array}{l}\text { Classification } \\
\text { (USCS) }\end{array}$ & \multicolumn{2}{|c|}{ SP } & $\begin{array}{c}\text { ASTM D2487- } \\
11 \\
\end{array}$ \\
\hline Specific gravity, Gs & \multicolumn{2}{|c|}{2.66} & $\begin{array}{c}\text { ASTM D854 - } \\
14 \\
\end{array}$ \\
\hline $\begin{array}{c}\text { Maximum unit } \\
\text { weight, } \gamma_{\mathrm{d}} \text { (max.) } \\
\mathrm{kN} / \mathrm{m}^{3} \\
\end{array}$ & \multicolumn{2}{|c|}{19.4} & $\begin{array}{c}\text { ASTM D4253 } \\
-14\end{array}$ \\
\hline $\begin{array}{c}\text { Minimum unit } \\
\text { weight, } \gamma_{\mathrm{d}}(\mathrm{min} .) \\
\mathrm{kN} / \mathrm{m}^{3}\end{array}$ & \multicolumn{2}{|c|}{15.8} & $\begin{array}{c}\text { ASTM D4254 } \\
-14\end{array}$ \\
\hline $\begin{array}{l}\text { Maximum void } \\
\text { ratio, } \mathrm{e}_{\max }\end{array}$ & \multicolumn{2}{|c|}{0.68} & \\
\hline $\begin{array}{l}\text { Minimum void ratio, } \\
\mathrm{e}_{\min }\end{array}$ & \multicolumn{2}{|c|}{0.371} & \\
\hline Relative density, $\%$ & $\begin{array}{c}\text { Medium } \\
=60\end{array}$ & $\begin{array}{c}\text { Dense }= \\
80\end{array}$ & \\
\hline $\begin{array}{l}\text { Dry unit weight }\left(\gamma_{\mathrm{d}}\right) \\
\mathrm{kN} / \mathrm{m}^{3}\end{array}$ & 17.75 & 18.5 & \\
\hline Void ratio & 0.55 & 0.44 & \\
\hline $\begin{array}{l}\text { Angle of internal } \\
\text { friction }(\varphi) \text {, deg. }\end{array}$ & 31.5 & 38.7 & $\begin{array}{c}\text { ASTM D3080 } \\
-11\end{array}$ \\
\hline
\end{tabular}

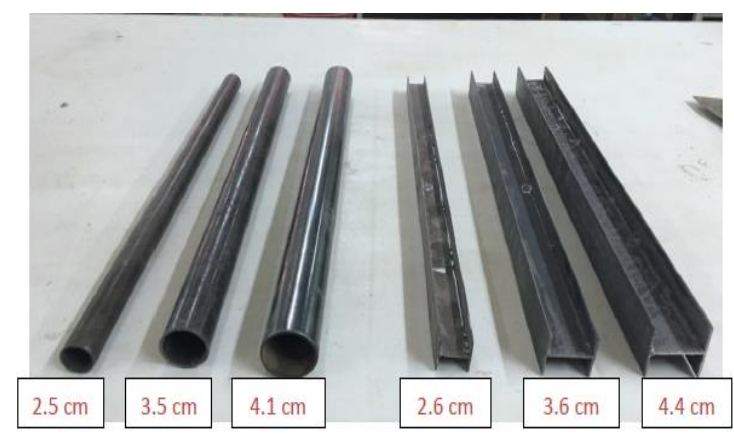

Fig. 3. Model piles used. 


\subsection{Calibration container and sample preparation}

All testing of piles model is carried out on dry sand samples compacted inside a steel container has dimensions $(100 \mathrm{~cm}$ length $\times 75 \mathrm{~cm}$ width $\times 70 \mathrm{~cm}$ depth $)$ as depicted in (Figure 4). The container has four wheels move freely on a rail fixed in the ground in form of a reversed T-section. Sand deposit was prepared as layers using a compacted solid plate hammer manufactured for this purpose with dimensions $(15 \mathrm{~cm} \times 15 \mathrm{~cm})$ and thickness of $5 \mathrm{~mm}$ connected with catcher of $30 \mathrm{~cm}$ in length.

According to the previous studies, the stress and displacement modes in the sand modeling are affected by sides of the soil container, additionally, due to the friction between the container walls and soil grains, the vertical stress in the sand can reduce with depth (Kraft, 1991) [12] . So, to eliminate the friction between soil grains and sides of the container; the height of the container $(\mathrm{Hc})$ to its diameter (Dc) should be not more one (in this study $\mathrm{Hc} / \mathrm{Dc}=70 / 75=0.93$ ) (Tarnet, 1999) [13].

During loading process or pile installation, soil surrounding the pile will be disturbed. This disturbance is extending to the concern zone depending to method of installation and relative density of soil. Previous studies detected that this zone is ranging in between (3D to $8 \mathrm{D}$ ) where $\mathrm{D}$ is the pile diameter (Robinsky and Morrison, 1964) [14]. Therefore, $\left(8 D_{\max }\right)$ are used $\left(D_{\max }\right.$ is the maximum pile diameter used in this study).

Two values of relative densities are chosen $(60 \%$ \& $80 \%$ ) to prepare medium and dense sand bed; this means that the weight of sand required in soil modeling is predetermined. Figure 4 explains the stages of sand preparation. Equal weights and lifts of seven layers are used to complete the soil bed; then the top layer is leveled using a ruler with sharp edges (The soil weight of each layer was compacted to desired depth which previously identified by lines drawn on the sides of container).
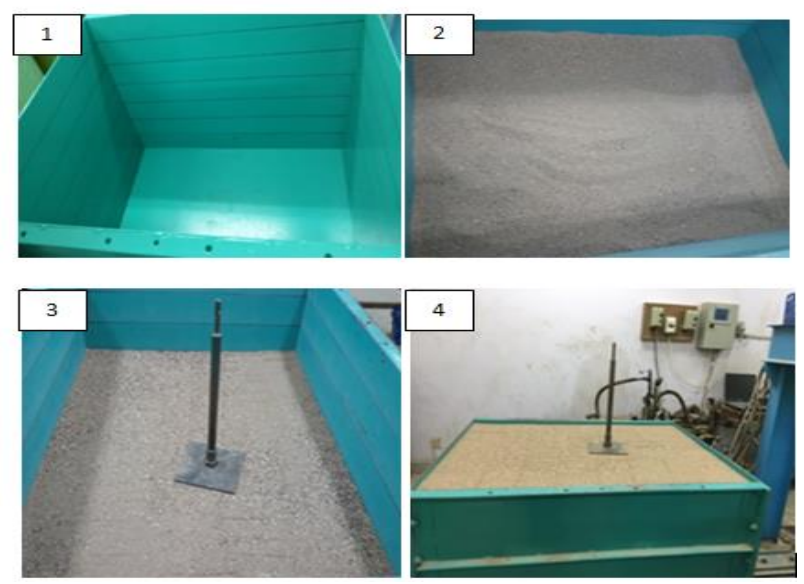

Fig. 4. Represents the steps of the sand deposit setup.

\subsection{Details of pile models}

After the completing the sand bed preparation inside the container, pile model is vertically inserted using a steel loading frame had been manufactured by (Ali, 2012) [15] as shown in Figure 5. So, to insure the vertically installation, pile driving system is modified by adding a base plate of $(86 \mathrm{~cm} \times 20 \mathrm{~cm})$ with thickness of $2 \mathrm{~cm}$. A pile holder is added above this system with different diameters (or widths of flange) depending on the pile type. For open ended piles, the pile holder is steel with dimensions $(10 \mathrm{~cm} \times 10 \mathrm{~cm} \times 2 \mathrm{~cm})$, while for $\mathrm{H}$-piles, the holder is made from wood with dimensions $(15 \mathrm{~cm} \times 15 \mathrm{~cm} \times 4 \mathrm{~cm})$ as shown in Figure 6 .

The axial loading on model is applied by hydraulic jack having a maximum loading capacity of ( 1 ton) with a manually adjusted to control on intensity of hydraulic. Load cell with maximum capacity of ( 2 ton) is used and connected with a digital weighing indicator with an input sensitivity of $(0.2 \mu \mathrm{N} /$ Digit $)$ to record the applied load.

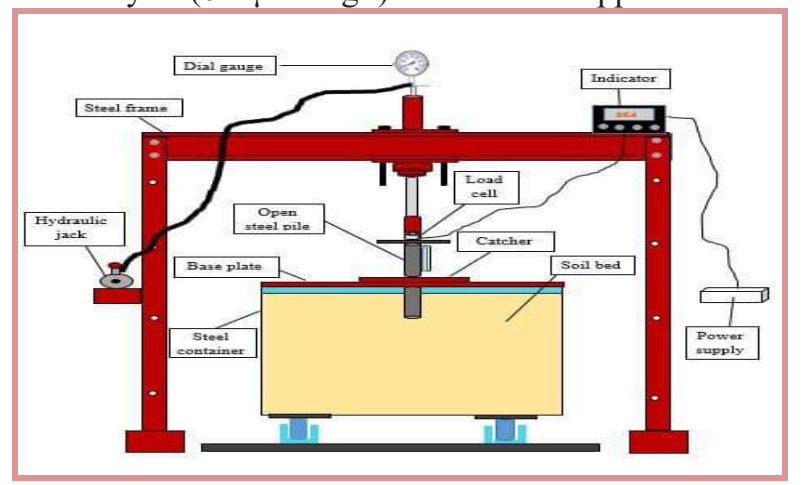

Fig.5. Steel loading frame.

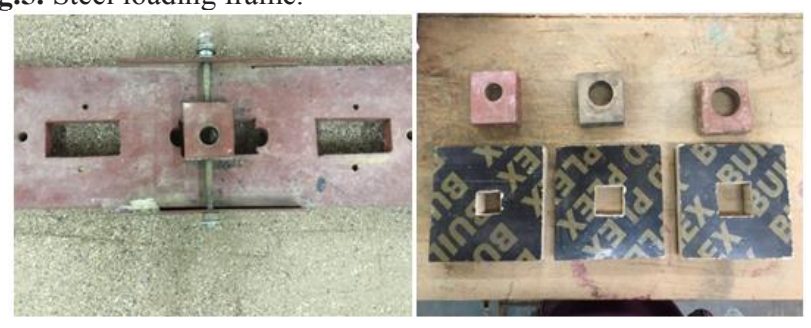

Fig.6. Base plates and holders.

\subsection{Testing program}

A total of 36 steel piles models are tested to attain the aim of this study. Eighteen pile models are used for each pile models (pipe piles with ends open and H-piles). To achieve the effect of amplitude load, two relative densities of sand are used (medium sand and dense sand). For each relative density, the load amplitude is chosen corresponding to (0.4) of static ultimate load capacity $\left(\mathrm{Quult}_{\mathrm{t}}\right.$, with (2) $\mathrm{Hz}$ frequency for each test.

An aluminum plate using as a center guide on the top of the pile was fixed, then the container moved along the rails and fixed in position in such a manner that the center of the aluminum base plate of the piston coincided with the center of the pile model. The static loading was applied gradually through the hydraulic jack that actuating at a controlled displacement of $0.03 \mathrm{~mm} / \mathrm{sec}$. The load was measured until the developed settlement exceeded $15 \%$ of the pile diameter according to ASTM D1143M-07 (2013). 
A special testing apparatus manufactured by Rahil (2007) [16] was used (Figure 7). The apparatus has the capability of applied monotonic and cyclic loads. The cyclic loading was applied in a sequence determined beforehand ( $40 \%$ of static load). Tests were leading to at (2) $\mathrm{Hz}$ frequency according to the loading value. The process of the loading was continued till the failure occurred or until the recorded settlement exceeded $15 \%$ of the pile diameter according to ASTM D1143M-07 (2013), the testing model device.

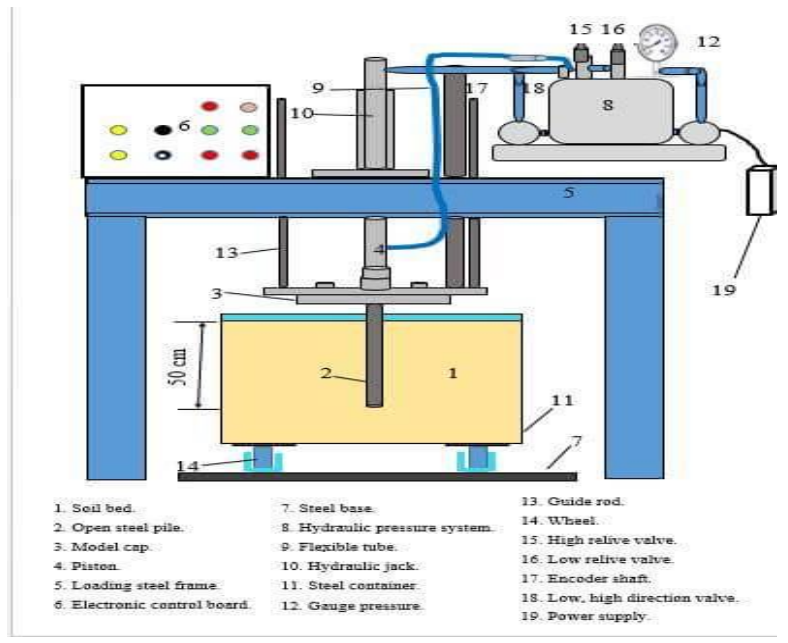

Fig.7. Testing model.

\section{Model Pile Test Results}

\subsection{Load -Settlement Relation}

All cyclic tests are depending on the ultimate load $\left(\mathrm{Q}_{\text {ult }}\right)$ values obtained from the static tests, therefore, a static test is carried out to concern the magnitude of cyclic loading needing to employ in cyclic testing of the piles models. The load-settlement curves for all piles are illustrated in Figures (8) to (13) and Table 2 represent a summary of the results. It can be see that H-pile carrying a load capacity greater than that of the open ended pipe pile about (13-136) \% and also the settlement of an open ended pipe pile is greater than that of H-pile under the same load and soil conditions. This means that the $\mathrm{H}-$ piles have a more resistance than open ends pipe piles.

\subsection{Embedded Length of the Pile and Number of Cycles Relation}

The form of the cyclic loading applied on piles model is of the forming close to the sinusoidal compressive type. All cyclic tests are depending on the ultimate load $\left(Q_{\text {ult }}\right)$ values obtained from the static tests. In cyclic loading the number of cycles of failure is taken as cycles required to causing $15 \%$ settlement of the pile diameter at any applied load.

Figures (14) and (15) depict the change of number of cycles with the embedded length of the piles. It can be observed that the number of cycles is linearly changing with embedded length of pile, whereby number of cycles decrease with increasing the length of pile and relative density for the same pile diameter to both piles type (open ended pipe and H-piles) that resulting due to increase in applied load.

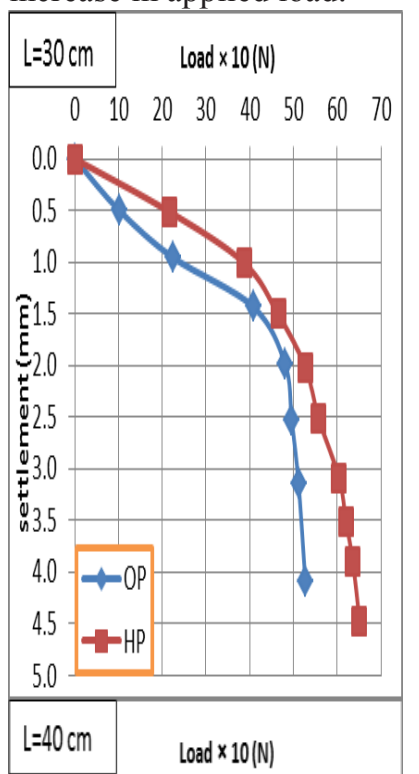

0102030405060708090100
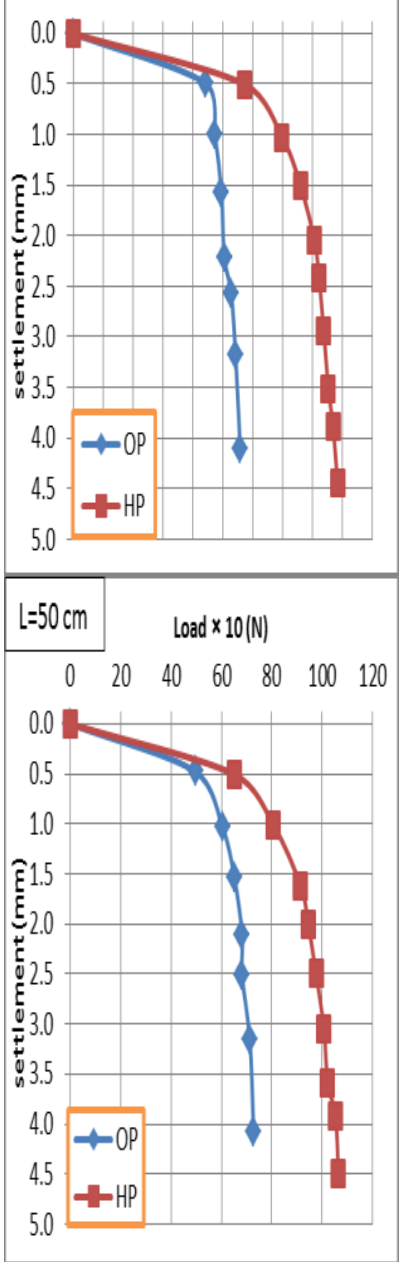

Fig.8. Load-settlement curve for open ended pipe and $\mathrm{H}-$ pile $(\mathrm{d}=2.5, \mathrm{~B}=2.6) \mathrm{cm}$ for $\mathrm{DR}=60 \%$.

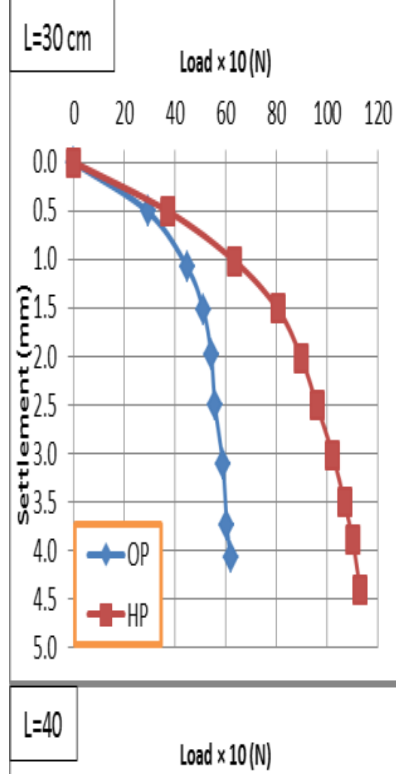

0255075100125150175200225
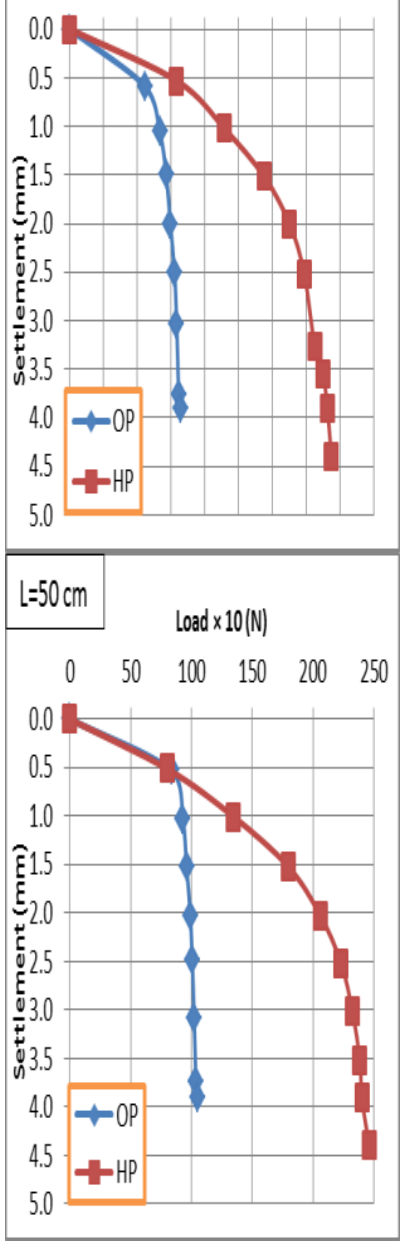

Fig.9. Load-settlement curve pile $(\mathrm{d}=2.5, \mathrm{~B}=2.6) \mathrm{cm}$ for $\mathrm{DR}=80 \%$. for open ended pipe and $\mathrm{H}$ - 

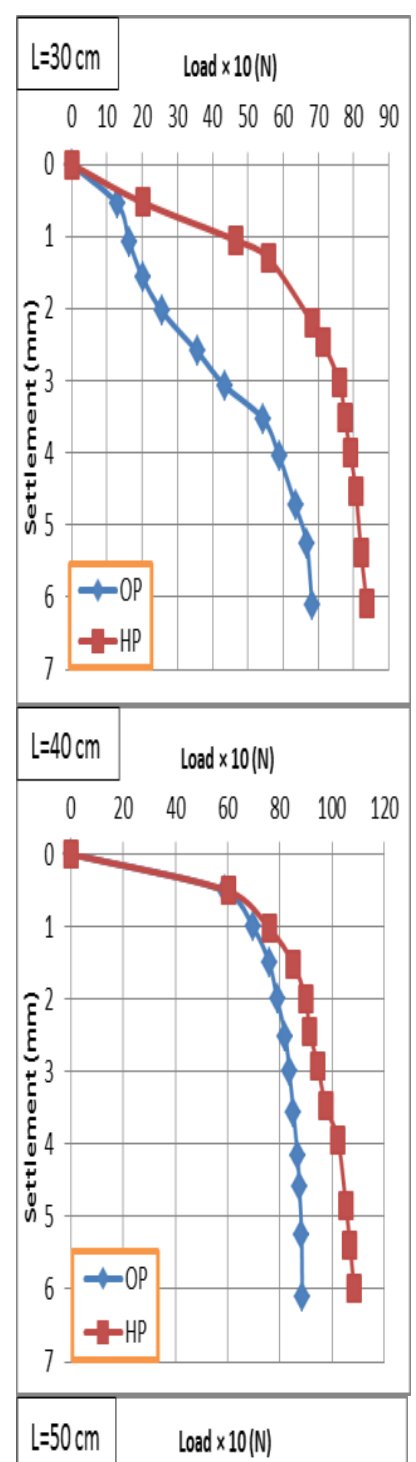

$\begin{array}{lllll}0 & 25 & 50 & 75 & 100125150175200\end{array}$

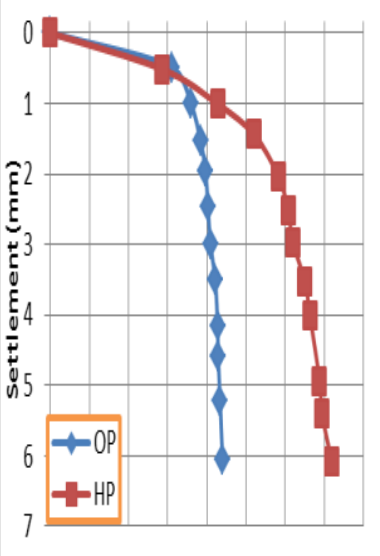

Fig. 10. Load-settlement curve for open ended pipe and H-pile $(\mathrm{d}=3.5, \mathrm{~B}=3.6) \mathrm{cm}$ for $\mathrm{DR}=60 \%$.

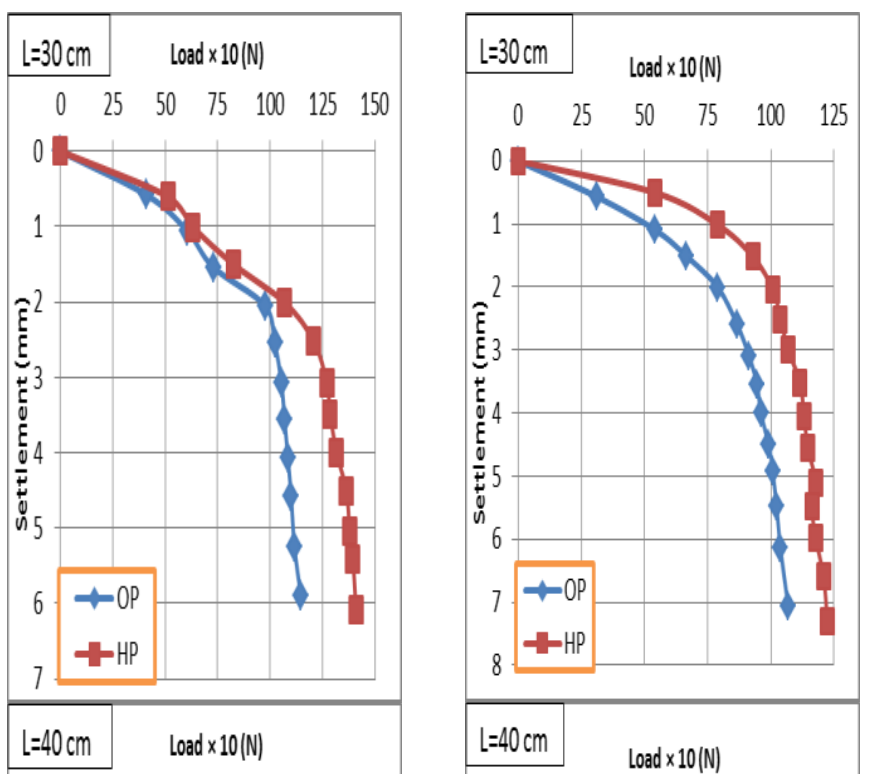

$0 \quad 25 \quad 50 \quad 75 \quad 100125150175200$
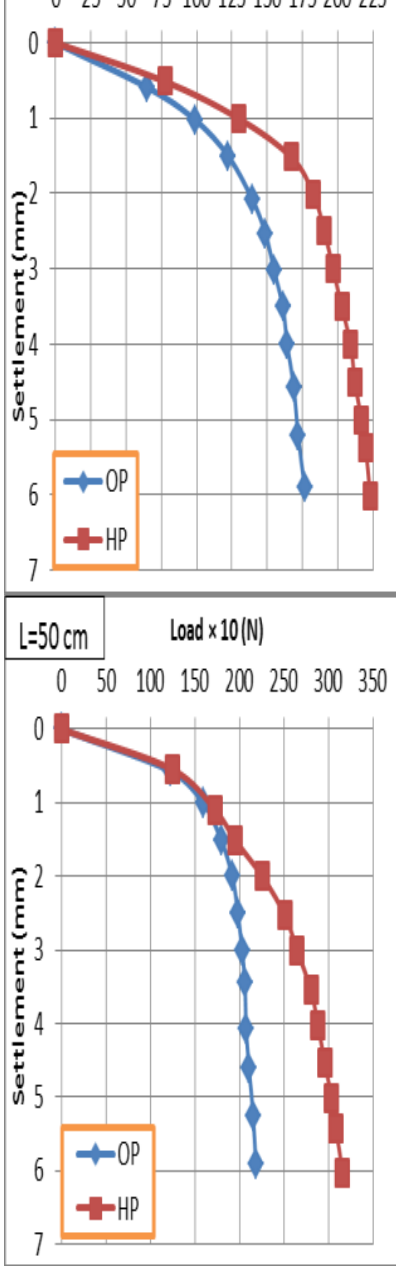

Fig. 11. Load-settlement curve for open ended pipe and $\mathrm{H}$-pile $(\mathrm{d}=3.5, \mathrm{~B}=3.6) \mathrm{cm}$ for $\mathrm{DR}=80 \%$.

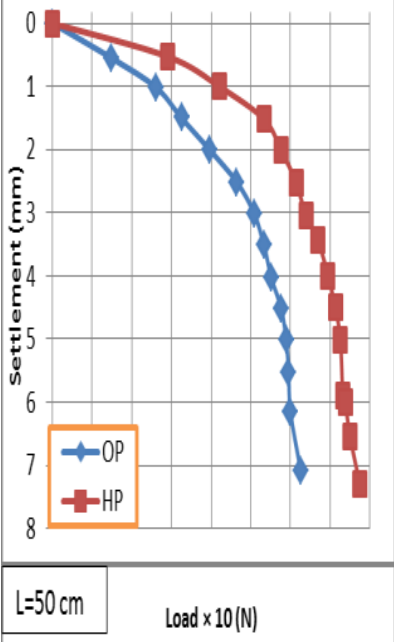

$0 \quad 255075100125150175200225$

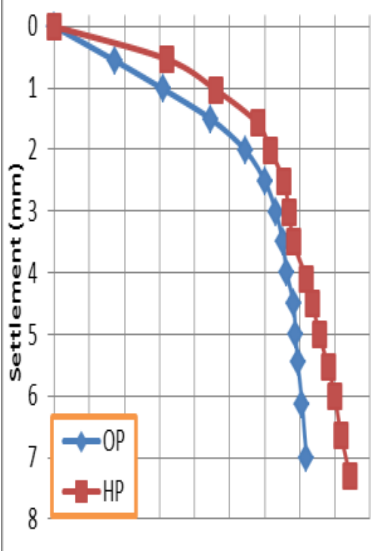

Fig. 12. Load-settlement curve for open ended pipe and H-pile ( $\mathrm{d}=4.1, \mathrm{~B}=4.4) \mathrm{cm}$ for $\mathrm{DR}=60 \%$.

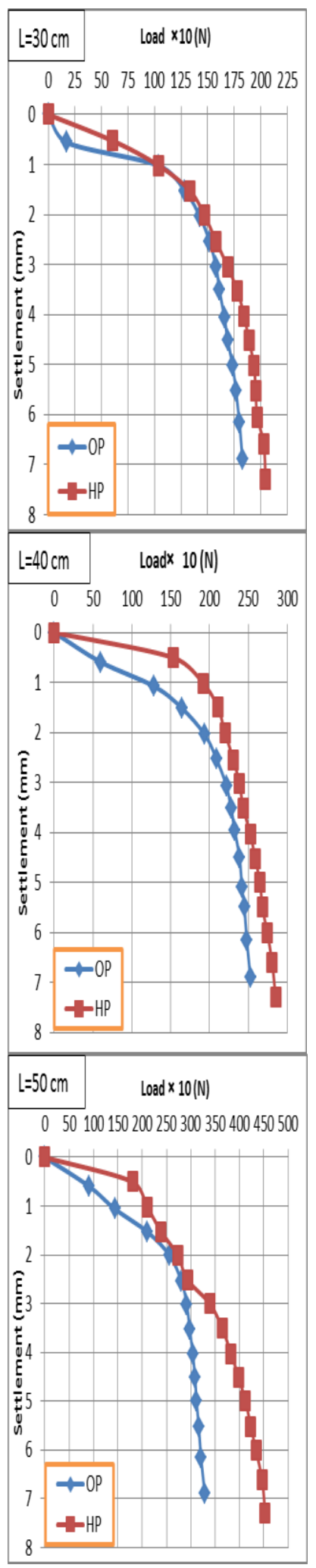

Fig. 13. Load-settlement curve for open ended pipe and H-pile ( $\mathrm{d}=4.1, \mathrm{~B}=4.4) \mathrm{cm}$ for $\mathrm{DR}=80 \%$. 
Table 2. Ultimate load capacity of open ended pipe and H pile.

\begin{tabular}{|c|c|c|c|}
\hline $\begin{array}{l}\text { Pile diameter } \\
\text { (d) } \\
\text { Flange width } \\
\text { (B) } \\
\text { (cm) }\end{array}$ & $\begin{array}{c}\text { Length of } \\
\text { pile, } \\
\text { L (cm) }\end{array}$ & $\begin{array}{c}\text { Qult } \\
\text { (N) } \\
\text { Open pile }\end{array}$ & $\begin{array}{c}\text { Qult } \\
\text { (N) } \\
\text { H pile }\end{array}$ \\
\hline \multicolumn{4}{|c|}{$\mathrm{DR}=60 \%$} \\
\hline \multirow{3}{*}{$\begin{array}{l}2.5 \\
2.6\end{array}$} & 30 & 511 & 635 \\
\hline & 40 & 543 & 868 \\
\hline & 50 & 713 & 1050 \\
\hline \multirow{3}{*}{$\begin{array}{l}3.5 \\
3.6\end{array}$} & 30 & 666 & 821 \\
\hline & 40 & 883 & 1069 \\
\hline & 50 & 1080 & 1736 \\
\hline \multirow{3}{*}{$\begin{array}{l}4.1 \\
4.4\end{array}$} & 30 & 1038 & 1209 \\
\hline & 40 & 1500 & 1875 \\
\hline & 50 & 1767 & 2040 \\
\hline \multicolumn{4}{|c|}{$\mathrm{DR}=80 \%$} \\
\hline \multirow{3}{*}{$\begin{array}{l}2.5 \\
2.6\end{array}$} & 30 & 605 & 1100 \\
\hline & 40 & 805 & 1906 \\
\hline & 50 & 1040 & 2402 \\
\hline \multirow{3}{*}{$\begin{array}{l}3.5 \\
3.6\end{array}$} & 30 & 1116 & 1395 \\
\hline & 40 & 1720 & 2200 \\
\hline & 50 & 2160 & 3084 \\
\hline \multirow{4}{*}{$\begin{array}{l}4.1 \\
4.4\end{array}$} & 30 & 1800 & 2030 \\
\hline & 40 & 2480 & 2805 \\
\hline & & & \\
\hline & 50 & 3208 & 4464 \\
\hline
\end{tabular}
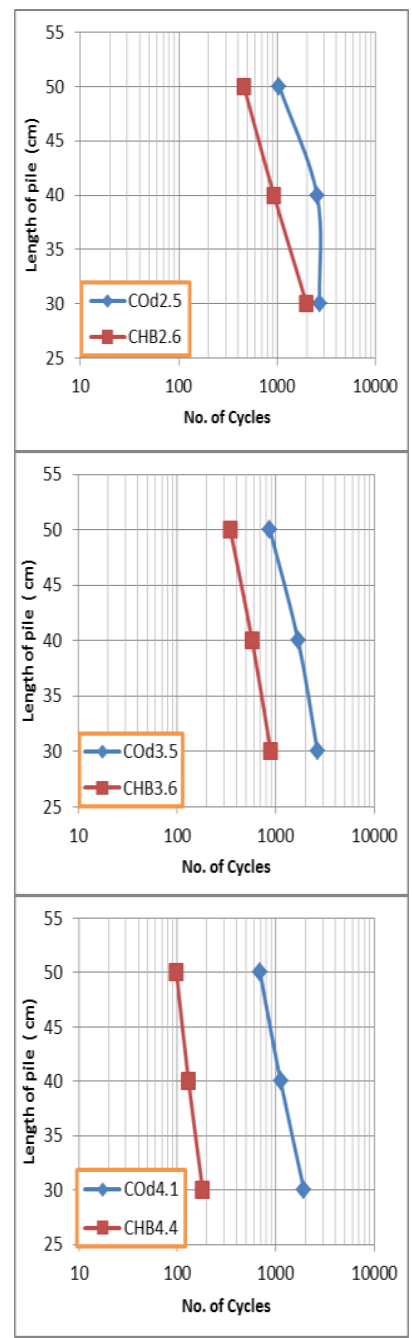

Fig. 14. Relationship between length of pile and No. of cycles for $\mathrm{DR}=60 \%$ under $\left(40 \% \mathrm{Q}_{\text {ult }}\right)$.
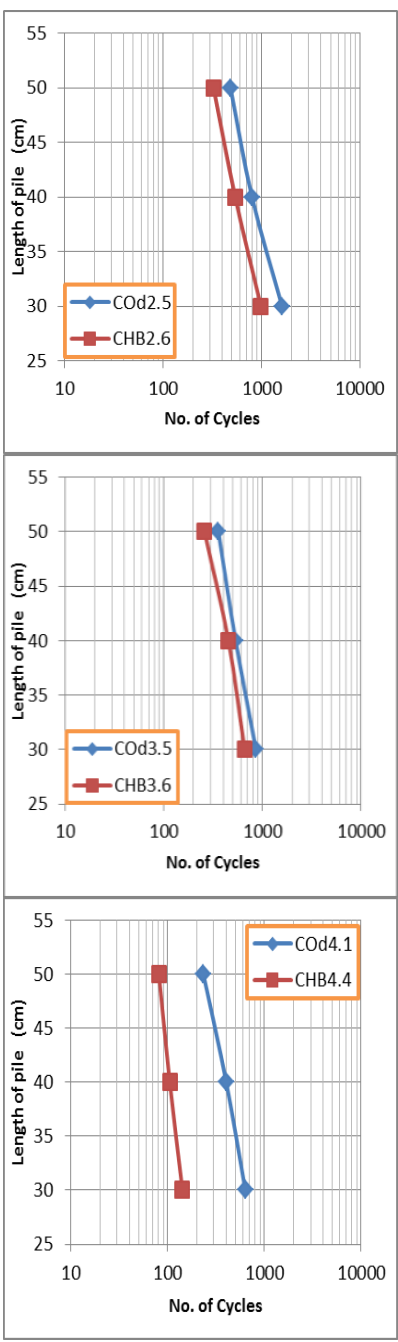

Fig. 15. Relationship between length of pile and No. of cycles for $\mathrm{DR}=80 \%$ under $\left(40 \% \mathrm{Q}_{\mathrm{ult}}\right)$.

\subsection{Pile Diameter and Number of Cycle Relation}

Increasing of pile diameter and relative density lead to the decreasing in number of cycles when the lengths of open ended pipe and H-piles are fixed as shown in Figures 16 and 17 . The variation of open pipe pile diameter has a small effect on number of cycles because the most shaft resistance is developed during installation process; also the displacement rapidly accumulates over just a few cycles. In H-Pile, a sharply changing is occurred when the width of flange decreased (from 4.4 $\mathrm{m}$ to $3.6 \mathrm{~m}$ ) because the displacements accumulate slowly, then this displacement accumulate rapidly. For the same pile length of both types of piles, the number of cycles decreased with increasing of pile diameter and relative density due to increase in applied load with increase in pile diameter and relative density at static load.

\subsection{Cycles Number - Settlement Curve}

The outcomes of number of cycles and settlement are illustrated in Figures (18) to (23). It can be observed that number of cycles decreased with increasing in the load amplitude, relative density and embedded length of piles for the same pile diameter.

\section{Conclusions}

The conclusions obtained from testing 36 models of piles under cyclic testing can list below:

1. H-Pile afforded a load capacity of about $(13-136)$ $\%$ greater than that of the open ended pipe piles under the same geometric conditions.

2. Pile geometry (diameter and length) and sand density have highly effect on the number of cycles. The variation of opened end pipe pile diameter has a small effect on number of cycles while decreasing the flange width of $\mathrm{H}$-Pile has more impact on increasing number of cycles.

3. Increasing of pile diameter (flange width) and relative density lead to the decreasing in number of cycles when the lengths of open ended pipe and $\mathrm{H}$ piles are fixed.

4. The number of cycles of the open ends piles is greater than that of the $\mathrm{H}$ - piles under the same geometric conditions (pile diameter, embedded length and sand density) especially in medium sand. 

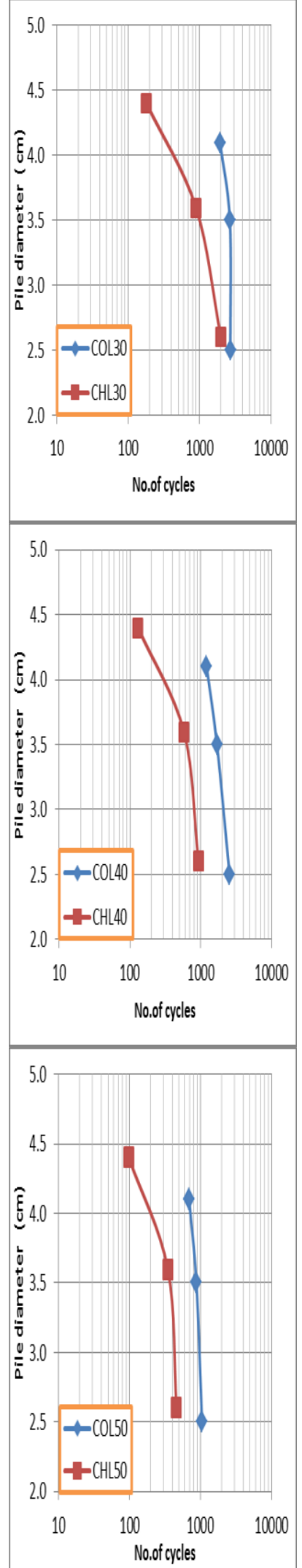

Fig.16. Relationship between length of pile and No. of cycles for $\mathrm{DR}=60 \%$ under (40\%Qult).
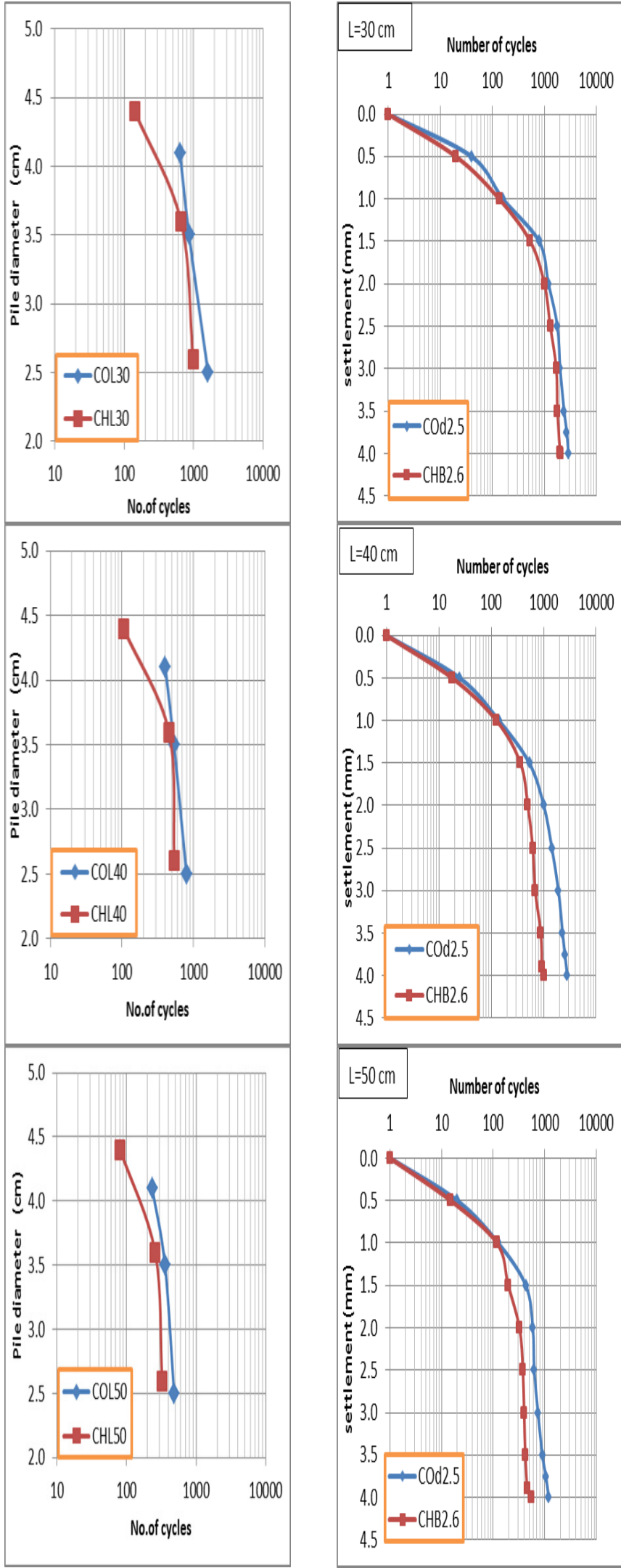

Fig.17. Relationship between length of pile and No. of cycles for $\mathrm{DR}=60 \%$ under (40\%Qult).
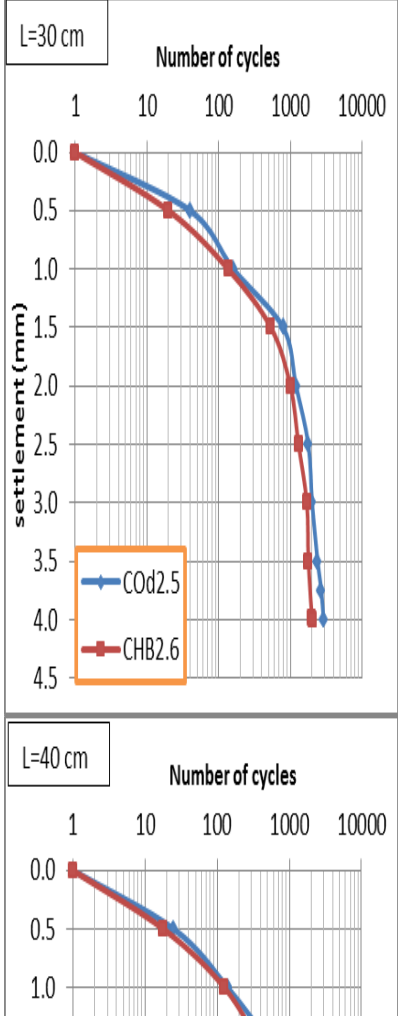

हิ
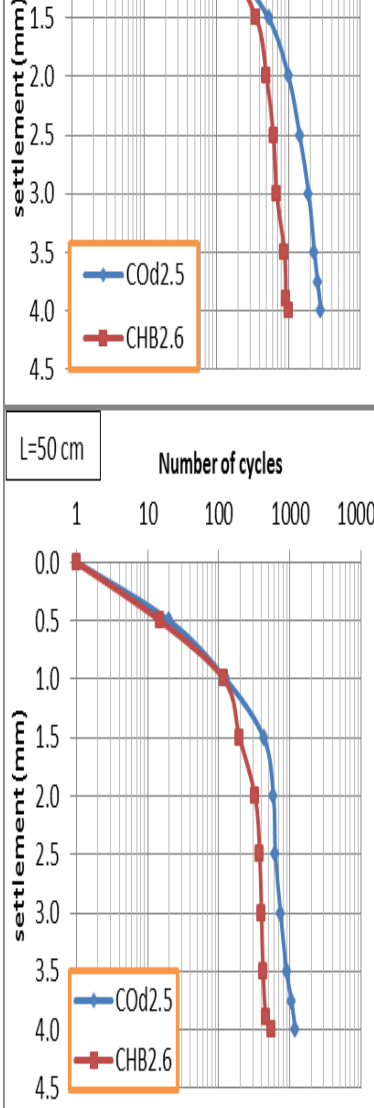

Fig.18. Number of cyclessettlement relation for $\mathrm{DR}=60 \%(\mathrm{~d}=2.5, \mathrm{~B}=2.6) \mathrm{cm}$.
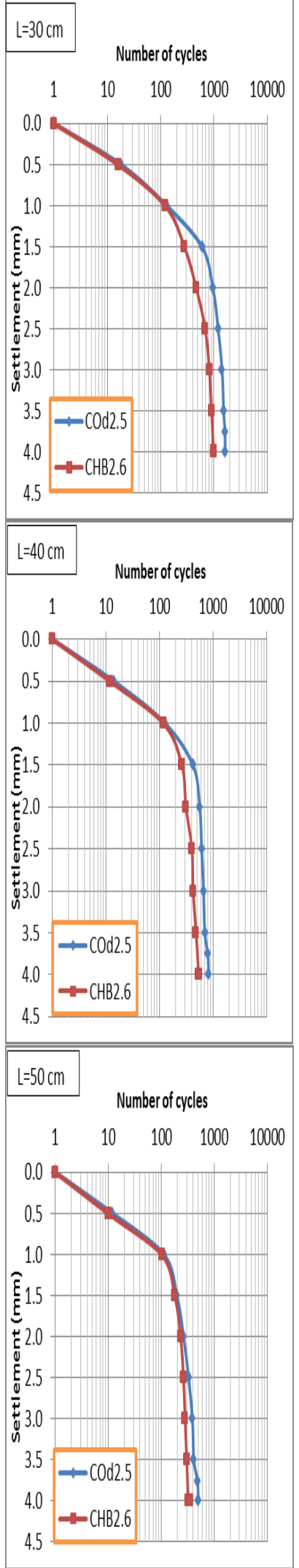

Fig.19. Number of cyclessettlement relation for $\mathrm{DR}=80 \%(\mathrm{~d}=2.5, \mathrm{~B}=2.6) \mathrm{cm}$. 


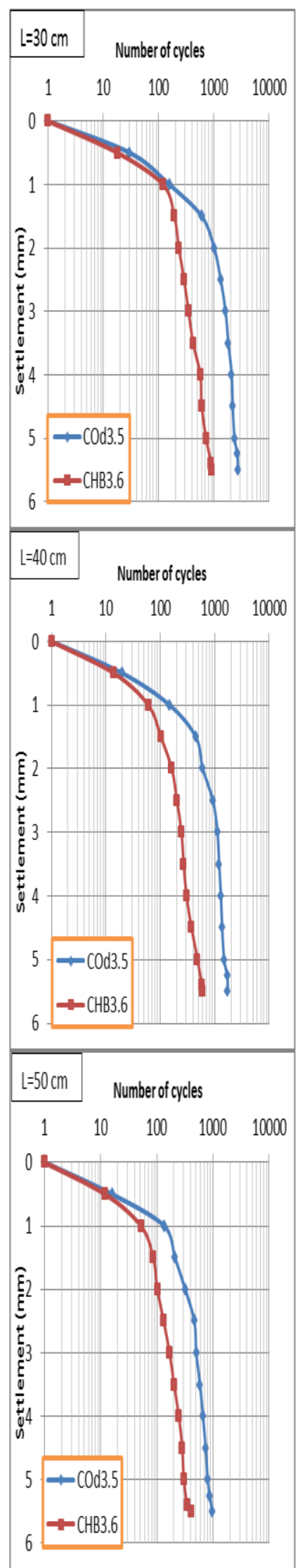

Fig. 20. Number of cyclessettlement relation for $\mathrm{DR}=60 \%(\mathrm{~d}=3.5, \mathrm{~B}=3.6) \mathrm{cm}$.

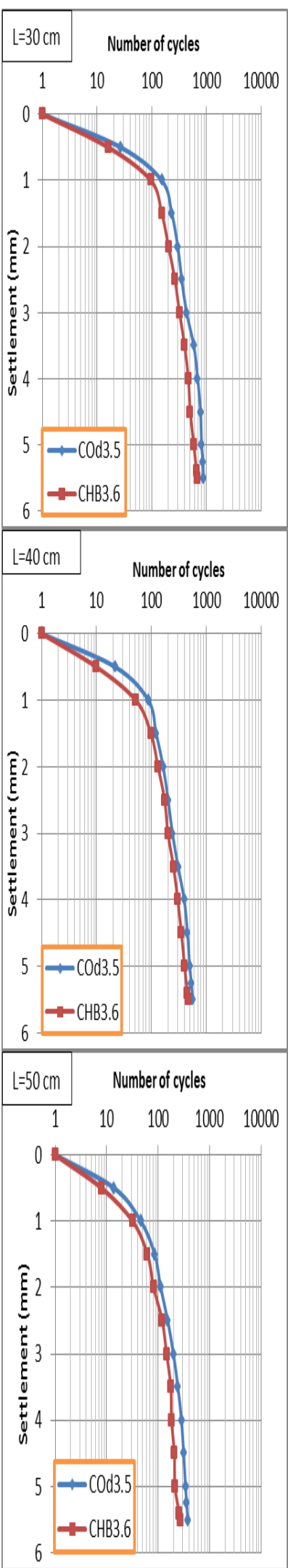

Fig. 21. Number of cyclessettlement relation for $\mathrm{DR}=80 \%(\mathrm{~d}=3.5, \mathrm{~B}=3.6) \mathrm{cm}$.
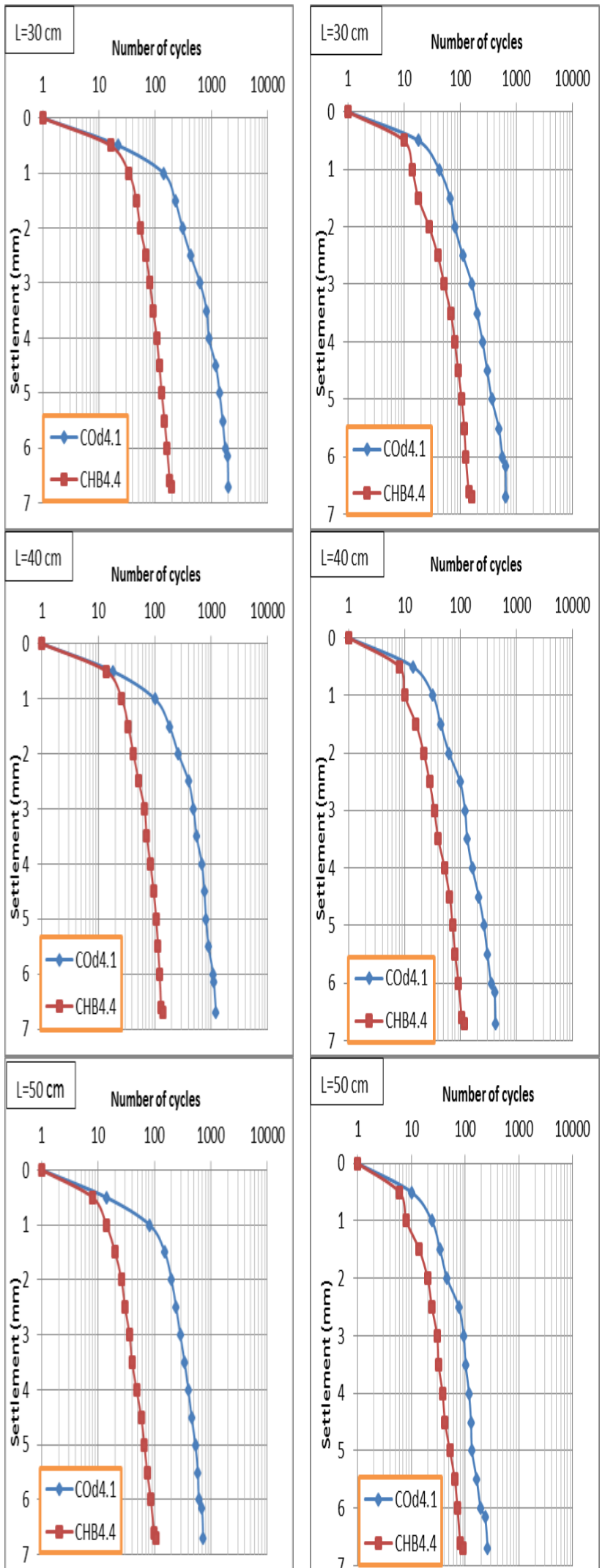

Fig. 22. Number of cyclessettlement relation for $\mathrm{DR}=60 \%(\mathrm{~d}=4.1, \mathrm{~B}=4.4) \mathrm{cm}$.

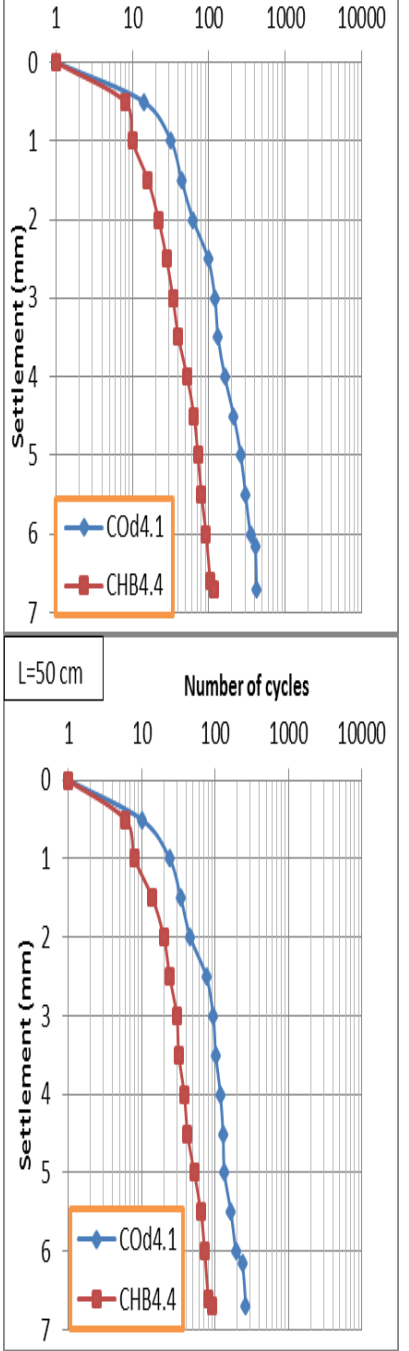

Fig. 23. Number of cyclessettlement relation for $\mathrm{DR}=80 \%(\mathrm{~d}=4.1, \mathrm{~B}=4.4) \mathrm{cm}$. 


\section{References}

1. C. G. di Prisco and D. M. Wood, Springer Vienna, (2012).

2. A. A. Puech, M. Boul on and Y. Meimon, Proc. $2^{\text {nd }}$ Int. conf. on numerical methods in offshore piling 293-312, (1982).

3. H. G. Poulos, Analysis and design of pile Foundations, ASCE, 99- 118, (1984).

4. H. G. Poulos, Geot. 39, No. 3, 365 - 41, (1989a).

5. H. G. Poulos, J. Geo. E., ASCE, 115, No.GT6, $836-$ 852. (1989b).

6. W. H. Craig and S. K. Sabagh, Can. Geot. J. 31, 2841 (1994).

7. R. J. Jardine and J. R. Standing, 1 \& 2. Offshore Tech. Report, Health and Safety Executive, London: 60 and 200, (2000).

8. R. J. Jardine and J. R. Standing, Soils and Foundations. 52, No. 4, 723 - 736, (2012).

9. F. Yu, J. Yang, LG Tham, P.K.K. Lee, ST, Geot., 56 No.. 4, 245-259,(2006).

10. F. Yu, 14, Bund. A. EJGE. (2008).

11. Z. Li, M. D. Bolton, and S. K. Haigh, Can. Geot. J. 49: 1074-1087 (2012).

12. L.M. Kraft, J. Geot. E., ASCE, 117 (2), 272-296, (1991).

13. O. Ternet, Ph.D. thesis, University of Caen, 184. (1999).

14. E. I. Robinsky, W. L. Sagar, and C. F. Morrison, Can. Geot. J., 1(4), 189-204, (1964).

15. A. M. Ali, (2012), M.Sc. Thesis, University of Technology, Iraq, (2012).

16. F. H. Rahil, PhD. Thesis, University of Technology, Iraq, (2007). 